\title{
Effects of future climate conditions on photosynthesis and biochemical component of Ulva pertusa (Chlorophyta)
}

\author{
Eun Ju Kang and Kwang Young Kim* \\ Department of Oceanography, Chonnam National University, Gwangju 61186, Korea
}

Ulva pertusa, a common bloom-forming green alga, was used as a model system to examine the effects of elevated carbon dioxide $\left(\mathrm{CO}_{2}\right)$ and temperature on growth and photosynthetic performance. To do this, U. pertusa was grown under four temperature and $\mathrm{CO}_{2}$ conditions; ambient $\mathrm{CO}_{2}(400 \mu \mathrm{atm})$ and temperature $\left(16^{\circ} \mathrm{C}\right)$ (i.e., present), elevated temperature only $\left(19^{\circ} \mathrm{C}\right)\left(\mathrm{ET}\right.$; i.e., warming), elevated $\mathrm{CO}_{2}$ only $(1,000 \mu \mathrm{atm})$ (EC; i.e., acidification), and elevated temperature and $\mathrm{CO}_{2}$ (ET and EC; i.e., greenhouse), and its steady state photosynthetic performance evaluated. Maximum gross photosynthetic rates $\left(\mathrm{GP}_{\max }\right)$ were highest under EC conditions and lowest under ET conditions. Further, ET conditions resulted in decreased rate of dark respiration $\left(\mathrm{R}_{\mathrm{d}}\right)$, but growth of $U$. pertusa was higher under ET conditions than under ambient temperature conditions. In order to evaluate external carbonic anhydrase (eCA) activity, photosynthesis was measured at $70 \mu \mathrm{mol}$ photons $\mathrm{m}^{-2} \mathrm{~s}^{-1}$ in the presence or absence of the eCA inhibitor acetazolamide (AZ), which inhibited photosynthetic rates in all treatments, indicating eCA activity. However, while AZ reduced $U$. pertusa photosynthesis in all treatments, this reduction was lower under ambient $\mathrm{CO}_{2}$ conditions (both present and warming) compared to EC conditions (both acidification and greenhouse). Moreover, Chlorophyll $a$ and glucose contents in $U$. pertusa tissues declined under ET conditions (both warming and greenhouse) in conjunction with reduced $\mathrm{GP}_{\max }$ and $\mathrm{R}_{\mathrm{d} \cdot}$. Overall, our results indicate that the interaction of EC and ET would offset each other's impacts on photosynthesis and biochemical composition as related to carbon balance of $U$. pertusa.

Key Words: acidification; $\mathrm{CO}_{2}$; greenhouse; photosynthesis; temperature; Ulva pertusa; warming

\section{INTRODUCTION}

Atmospheric concentrations of carbon dioxide $\left(\mathrm{CO}_{2}\right)$ have rapidly increased since the time of the Industrial Revolution, leading to changes in the chemical composition of seawater. The A1FI scenario of the Intergovernmental Panel on Climate Change (IPCC) projects that the the atmospheric $\mathrm{CO}_{2}$ concentration will have increased to $970 \mu$ atm nearly three times the present concentration by the end of the current century (IPCC 2007). Concomitantly, the average $\mathrm{pH}$ of seawater is expected to drop by ap- proximately 0.46 units from current levels, with both $\mathrm{CO}_{2}$ and $\mathrm{HCO}_{3}{ }^{-}$concentrations increasing and $\mathrm{CO}_{3}{ }^{2-}$ decreasing. These changes caused by increasing atmospheric $\mathrm{CO}_{2}$ will also be associated with increased ocean temperature and acidity, sea-level rise, and more frequent natural disasters (IPCC 2007, Doney et al. 2009). There is general agreement that these impacts will be some of the most notable environmental changes in the ocean during the coming decades (e.g., Hansen et al. 2005).
(9) $\$$ This is an Open Access article distributed under the terms of the Creative Commons Attribution Non-Commercial License (http://creativecommons.org/licenses/by-nc/3.0/) which permits unrestricted non-commercial use, distribution, and reproduction in any medium, provided the original work is properly cited.
Received December 27, 2015, Accepted March 9, 2016

* Corresponding Author

E-mail: kykim@chonnam.ac.kr

Tel: +82-62-530-3465, Fax: +82-62-530-0065 
There are several potential biological implications of the expected environmental changes associated with ocean acidification. For example, current $\mathrm{CO}_{2}$ concentrations, in the form of dissolved inorganic carbon (DIC) in seawater, are not high enough to saturate photosynthesis of marine primary producers, and therefore, photosynthesis in macroalgae and phytoplankton could be saturated under current $\mathrm{CO}_{2}$ conditions by using carbon concentration mechanisms (CCMs) (Raven 1997), such as those associated with the enzyme carbonic anhydrase (CA), which catalyzes dehydration of $\mathrm{HCO}_{3}{ }^{-}$to $\mathrm{CO}_{2}$. However, the exact mechanisms by which this occurs may differ at phylogenetic levels, from ecotypes to phyla (Johnston et al. 1992, Mercado et al. 1997, Brading et al. 2011). Indeed, most macroalgae involve CCMs and thus use $\mathrm{HCO}_{3}{ }^{-}$for photosynthesis; however, photosynthesis dose not generally appear saturated under present DIC conditions (Koch et al. 2013). From previous research, several species of Ulva have shown variation in acclimations to changes in DIC, such as the use of $\mathrm{HCO}_{3}{ }^{-}$, the extent of carbonic anhydrate activity, and DIC saturation states. Indeed, many researchers predicted that the change in ocean $\mathrm{CO}_{2}$ concentrations could directly affect $\mathrm{CCM}$ activities in many species because increased $\mathrm{CO}_{2}$ enhances the dependence of carbon by diffusion. In addition, the down-regulation of CCMs appears through decreased $\mathrm{HCO}_{3}^{-}$usage and increased reliance on $\mathrm{CO}_{2}$ utilization, and mechanism that has been supported by many laboratory and in situ experiments (Gao et al. 2012).

Some metabolic changes including photosynthesis, respiration, and enzyme activity occur as a result of increased temperature (Atkin et al. 2000, Atkin and Tjoelker 2003, Vona et al. 2004), which in turn, alters the physiological responses of the macroalgae to environmental changes (Kübler and Davison 1995, Zou and Gao 2013). Simultaneously, increased atmospheric $\mathrm{CO}_{2}$ will result in ocean acidification and many unpredictable effects (Doney et al. 2009). Considerable research was carried out on the impacts of these factors; however, most has focused primarily on the processes of biological calcification, the general impacts on phytoplankton communities, and only a few have focused on selected macroalgae. Further, few of these studies have considered the combined impacts of these environmental changes on a bloom-forming green alga using ecologically relevant conditions (e.g., $\mathrm{Xu}$ and Gao 2012). Here, we consider the impact of these factors on $U$. pertusa using environmentally relevant levels of $\mathrm{CO}_{2}$ and temperature.

Ulva species, the globally important bloom-forming green algae, grow in a wide range of temperatures, rang- ing from $10-30^{\circ} \mathrm{C}$, with the highest growth rates generally occurring at $15-20^{\circ} \mathrm{C}$ (Taylor et al. 2001). Likewise, the sporelings of $U$. intestinalis (Enteromorpha intestinalis) grow in a wide range of temperatures, with the highest growth rates occurring at 15 and $20^{\circ} \mathrm{C}$ (Kim and Lee 1996). Further, the floating $U$. linza, collected in the early summer from the Yellow Sea, exhibits exponential growth at $10-15^{\circ} \mathrm{C}$, and tissue senescence occurs at temperatures over $20^{\circ} \mathrm{C}$, but gross photosynthesis (GP) is higher at 20$25^{\circ} \mathrm{C}$ (Kim et al. 2011, Kang et al. 2016). In $U$. rigida higher growth occurs below $17^{\circ} \mathrm{C}$, whereas growth declines above $17^{\circ} \mathrm{C}$ (de Casabianca et al. 2002). U. pertusa from eelgrass beds in Korea exhibit high growth rates at temperatures between 10 and $25^{\circ} \mathrm{C}$ (Choi 2003). Together, these different growth rates reflect the temperature regimes these algae experience in natural habitats, and reflect the seasonality and distribution of each species (Gessner 1970, Innes 1988, Lüning 1990).

Considerable research has demonstrated that photosynthetic rates of marine plants are enhanced by increased $\mathrm{CO}_{2}$ concentrations. However, photosynthetic activity depends not only on $\mathrm{CO}_{2}$ concentration but also on nutrient levels, light and temperature conditions (Zimmerman et al. 1997, Gordillo et al. 2001, 2003, Fu et al. 2007, Zou et al. 2011). For example, the marine picocyanobacteria Synechococcus and Prochlorococcus were examined under four conditions that combined changes in $\mathrm{CO}_{2}$ concentration and temperature (Fu et al. 2007). Growth and photosynthesis of Prochlorococcus were unaffected by increasing $\mathrm{CO}_{2}$ and temperature, whereas growth and photosynthesis in Synechococcus were stimulated by increasing temperature, but showed synergistic responses with increasing $\mathrm{CO}_{2}$ and temperature. The recruitment of algal turfs (mainly Feldmannia spp.) also has shown synergistic responses when exposed to combined future $\mathrm{CO}_{2}$ and temperature conditions, with biomass increased two-fold relative to when the turfs were exposed to the single effects of either $\mathrm{CO}_{2}$ or temperature alone (Connell and Russell 2010). Further, the effective quantum yield of algal turfs also increases when exposed to future $\mathrm{CO}_{2}$ conditions, but decreases when exposed to elevated temperature alone. Olabarria et al. (2013) observed that both individuals and assemblages of rockpool macroalgae exhibit various responses to increased $\mathrm{CO}_{2}$ and high temperature. Specifically, increased $\mathrm{CO}_{2}$ and temperature resulted in decreases in macroalgae assemblage biomass because of changes in productivity and respiration. However, these experiments have not previously been conducted with a green tide forming eukaryotic alga where the impacts on natural communities may 
be extreme.

Ulva pertusa (Chlorophyta) is a green tide species with outbreaks occurring in many coastal areas of Korea (Kim et al. 2004). Blooms of $U$. pertusa, are associated with elevated nutrients, especially nitrogen and phosphorous, and partially regulated by temperature, light and biotic factors (Valiela et al. 1997, Giannotti and McGlathery 2001). Despite the extensive understanding of the factors associated with green tide outbreaks, there are a few studies that allow us to predict the potential impacts of elevated atmospheric $\mathrm{CO}_{2}$ levels and consequent climate change on these blooms. In this study we simultaneously evaluate the impacts of both elevated $\mathrm{CO}_{2}$ and temperature on the growth of $U$. pertusa. We focus on biochemical composition, respiration, photosynthetic responses and growth rates as adaptations of $U$. pertusa to realistic future climate conditions.

\section{MATERIALS AND METHODS}

\section{Sample collection and incubation}

U. pertusa was collected in December 2010 from the intertidal zone at Wando $\left(34^{\circ} 19^{\prime} 30^{\prime \prime} \mathrm{N}, 126^{\circ} 49^{\prime} 50^{\prime \prime} \mathrm{E}\right)$, on the southern coast of Korea. Ulva species, especially $U$. pertusa and $U$. linza are predominant in this area during winter. The average water temperature and salinity were $10^{\circ} \mathrm{C}$ and $\mathrm{S}=32$, respectively at the time of sampling. The samples were rinsed in filtered seawater to remove macroscopic epiphytes and were maintained in filtered, aerated seawater supplemented with F/2 nutrients (FRITZ Industries Inc., Greenville, TX, USA). Thalli were initially maintained at conditions of $16^{\circ} \mathrm{C}, \mathrm{S}=32$, and $70 \mu \mathrm{mol}$ photons $\mathrm{m}^{-2} \mathrm{~s}^{-1}$, and a $12: 12 \mathrm{~h}$ light : dark cycle for 3 days prior to experimental initiation.

\section{Experimental design}

Four treatments were used to measure the individual and combined effects of $\mathrm{CO}_{2}$ and temperature: ambient $\mathrm{CO}_{2}(400 \mu \mathrm{atm})$ and temperature $\left(16^{\circ} \mathrm{C}\right)$ (i.e., present); ambient $\mathrm{CO}_{2}$ and elevated temperature $\left(19^{\circ} \mathrm{C}\right)(\mathrm{ET}$; i.e., warming); elevated $\mathrm{CO}_{2}(1,000 \mu \mathrm{atm})$ and ambient temperature (EC; i.e., acidification); and both elevated temperature and $\mathrm{CO}_{2}$ (ET and EC combined; i.e., greenhouse). Different $\mathrm{CO}_{2}$ concentrations were provided by mixing air with the appropriate amounts of $\mathrm{CO}_{2}$ obtained from a compressed $\mathrm{CO}_{2}$ cylinder, as described by Kim et al. (2008). Carbon dioxide $\left(\mathrm{CO}_{2}\right)$ concentrations were monitored in the resulting air- $\mathrm{CO}_{2}$ mixtures using a $\mathrm{CO}_{2}$ analyzer (LI-840A; LI-COR, Lincolon, NE, USA). These mixtures were bubbled through the media, and $\mathrm{CO}_{2}$ was monitored daily via measurements of the $\mathrm{pH}$ of culture media using a pH-meter (Meterlab PHM210; Radiometer Analytical SAS, Lyon, France). The maximum variation of $\mathrm{CO}_{2}$ in individual cultures was $5 \%$, and $\mathrm{CO}_{2}$ inputs were adjusted daily in order to maintain constant levels in each experimental treatment.

Total seawater alkalinity (TA) and total DIC were measured with a potentiometric titration system (765 Dosimat; Metrohm AG, Herisau, Switzerland), combined with a ROSS half-cell pH electrode (Orion 8101BNWP; Thermo Scientific, Waltham, MA, USA) and a sure-flow reference electrode (Orion 900200; Thermo Scientific). Proportions of the carbon species in the seawater were calculated from the TA and DIC values using CO2SYS software (Lewis and Wallace 1998). The TA and DIC measurements were checked for accuracy against certified reference materials (distributed by A. Dickson, Scripps Institution of Oceanography) used here as standards. The precisions of the measurement were approximately $\pm 2 \mu \mathrm{mol} \mathrm{kg}^{-1}$ for TA and $\pm 1.5 \mu \mathrm{mol} \mathrm{kg}^{-1}$ for DIC. Temperature and irradiance were also monitored using a temperature/light data logger (UA-002-64; Onset, Pocasset, MA, USA) calibrated with a thermometer during the experiment. The experimental temperatures were controlled using aquarium heaters (EHEIM Jager, Deizisau, Germany). Temperatures were maintained to within $0.1^{\circ} \mathrm{C}$ of the targeted temperature throughout the experiment.

\section{Photosynthetic rates}

Photosynthetic rates were measured using an oxygen closed-chamber method consisting of a 2-mm oxygen dipping probe (DP-PSt3) connected to Fibox3 (PreSens, Regenburg, Germany) at eight irradiances (0, 10, 45, 80, 150,245 , and $450 \mu \mathrm{mol}$ photons $\left.\mathrm{m}^{-2} \mathrm{~s}^{-1}\right)$ derived from a halogen lamp (KL2500; SCHOTT, Mainz, Germany). Temperature and $\mathrm{CO}_{2}$ concentrations were maintained at each target level during the photosynthetic measurement. The photosynthesis-irradiance relationships for distinction of photosynthetic traits were fitted to a nonlinear mathematical function that represented the double exponential function (Platt et al. 1980).

\section{External CA activities}

In order to assess the external carbonic anhydrase (eCA) activity, photosynthesis was measured with and 
without acetazolamide (AZ) under $70 \mu \mathrm{mol}$ photons $\mathrm{m}^{-2}$ $\mathrm{s}^{-1}$. AZ inhibits photosynthesis using $\mathrm{HCO}_{3}^{-}$, hence the results show $\mathrm{CO}_{2}$ utilized during photosynthesis when $\mathrm{AZ}$ was added to the seawater media. AZ was prepared in 0.5 $\mathrm{N} \mathrm{NaOH}$ and added to the medium at a concentration of $60 \mu \mathrm{M}$. Experiments with AZ used the same irradiance levels as were used in the incubation conditions.

\section{Chlorophyll $a(\mathrm{Chl} a)$ fluorescence}

Chl $a$ fluorescence was measured using Diving-PAM (Walz GmbH, Effeltrich, Germany). Effective quantum yield $\left(\Phi_{\mathrm{PSII}}\right)$ was calculated as:

$$
\Phi_{\mathrm{PSII}}=\left(F_{\mathrm{m}}{ }^{\prime}-F\right) / F_{\mathrm{m}}{ }^{\prime}
$$

, where $F$ and $F_{\mathrm{m}}{ }^{\prime}$ represent the steady-state fluorescence and maximum fluorescence measured in the light, respectively. Rapid light curves (RLC) were determined according to Ralph and Gademann (2005). Relative electron transport rate $(r \mathrm{ETR})$ was calculated as:

$$
r \mathrm{ETR}=\Phi_{\mathrm{PSII}} \times \text { irradiance }
$$

, with two ambiguous factors (the partitioning of light energy by photosystem [PS] I and PSII, and the absorption factor) were not considered. Chl $a$ fluorescence parameters from $r$ ETR-irradiance curves were calculated using a nonlinear regression equation (Platt et al. 1980).

\section{Growth rates}

$U$. pertusa thalli were prepared by slicing individual $20 \mathrm{~mm}$ diameter disks from near the base of each thallus using a cork borer. To reduce the effects of damage at the disk margins, disks were cut one day prior to the start of the growth experiment. The growth rate $(\mu)$ was calculated as:

$$
\mu=\ln \left(A-A_{0}\right) /\left(T-T_{0}\right)
$$

, where $\mathrm{A}$ and $\mathrm{A}_{0}$ represent the areas at time $\mathrm{T}$ (after 10 days) and $\mathrm{T}_{0}$ (the initial day), respectively.

\section{Chl $a$, tissue nutrient, and glucose contents}

Chl $a$ contents were determined using a spectrophotometer (Helios a UV-Vis; Unicam, Cambridge, UK). Each $U$. pertusa disk that was used to evaluate growth above was extracted in $20 \mathrm{~mL}$ glass vials with $8 \mathrm{~mL}$ of $\mathrm{N}, \mathrm{N}$-di- methylformamide at $4^{\circ} \mathrm{C}$ for $24 \mathrm{~h}$ in the dark. The Chl $a$ content was calculated as:

$$
\text { Chl } a\left(\mathrm{mg} \mathrm{L}^{-1}\right)=12.70 A_{664.5}-2.97 A_{647}
$$

, where $A_{664.5}$ and $A_{647}$ represent absorbance at $664.5 \mathrm{~nm}$ and $647 \mathrm{~nm}$, respectively (Inskeep and Bloom 1985).

Carbon $(\mathrm{C})$ and nitrogen $(\mathrm{N})$ contents within the $U$. pertusa tissues were determined from individual disks using an elemental analyzer (EA 1110; CE Instruments, Milan, Italy). Samples were dried at $60^{\circ} \mathrm{C}$ for $24 \mathrm{~h}$, and homogenized by mill grinding (Mixer Mill MM301; Retsch, Hann, Germany). Tissue phosphorous (P) was extracted using an alkaline persulfate digestion, and determined using a standard colorimetric phosphate protocol (Menzel and Corwin 1965).

Glucose content within the U. pertusa tissues was determined by using 3,5-dinitrosalicylic acid to measure reducing sugar (Wood and Bhat 1988); $70 \mathrm{~mL}$ of $0.1 \mathrm{M} \mathrm{HCl}$ was added to $3 \mathrm{~g}$ of dried sample in an Erlenmeyer flask, and reducing sugar was extracted by autoclaving at $121^{\circ} \mathrm{C}$ and $1.5 \mathrm{~atm}$ for $15 \mathrm{~min}$.

\section{Statistical analysis}

All statistical analyses were performed using the SPSS 20.0 statistical software. Data normality and homogeneity of variance were determined using the KolmogorovSmirnov normality test and Levene's homogeneity of variance test, respectively. One-way analysis of variance (ANOVA) and two-way ANOVAs were used to compare the effects of $\mathrm{CO}_{2}$ concentrations and temperatures on photosynthetic parameters, growth rate, $\mathrm{Chl} a$ concentration, and reducing sugar. Nonparametric tests (Kruskal-Wallis test) were conducted for data that were not normally distributed. When significant differences were detected, specific differences between treatment pairs were determined using Tukey's multiple comparisons. A pairedsample t-test was used to aid in differentiating the eCA activity before and after the addition of eCA inhibitor.

\section{RESULTS}

\section{Photosynthesis and $\mathrm{Chl} a$ fluorescence}

Gross photosynthesis (GP) in U. pertusa determined from the photosynthesis-irradiance (P-E) curves did not vary significantly among the four $\mathrm{CO}_{2}$ and temperature treatments. Further, GP was saturated at 100-150 $\mu \mathrm{mol}$ 


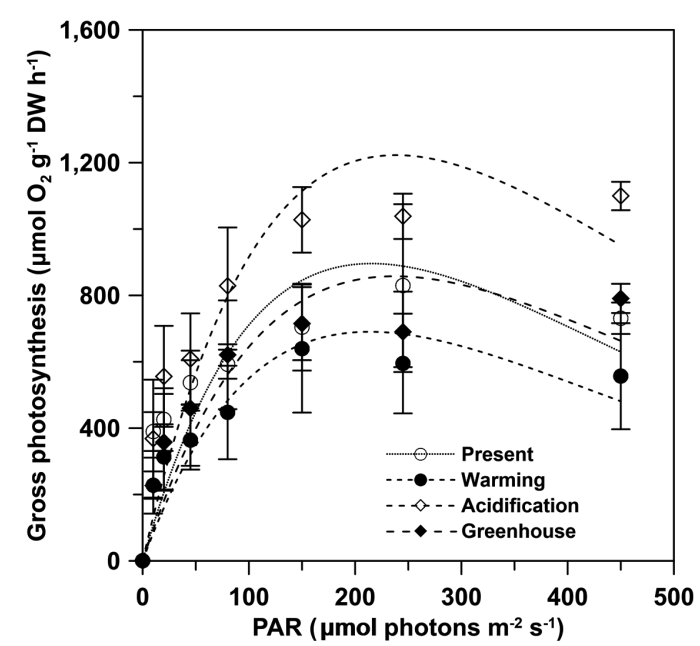

Fig. 1. Photosynthesis versus irradiance curves of Ulva pertusa under four $\mathrm{CO}_{2}$ and temperature conditions. PAR, photosynthetic active radiation, i.e., irradiance. Data are presented as mean \pm standard deviation $(n=3)$.

photons $\mathrm{m}^{-2} \mathrm{~s}^{-1}$ and either decreased or reached a plateau over $150 \mu \mathrm{mol}$ photons $\mathrm{m}^{-2} \mathrm{~s}^{-1}$ in all treatments (Fig. 1). However, GP in the acidification treatment showed distinctly higher photosynthesis and was 1.2-2 fold higher when the alga was exposed to over $150 \mu \mathrm{mol}$ photons $\mathrm{m}^{-2}$ $\mathrm{s}^{-1}$ under all measured irradiances. The photosynthetic parameters obtained from the P-E curves are shown in Table 1. Maximum gross photosynthetic rates $\left(\mathrm{GP}_{\max }\right)$ were greatest $\left(1,046.9 \pm 66.5 \mu \mathrm{mol} \mathrm{O}_{2} \mathrm{~g}^{-1} \mathrm{DW} \mathrm{h}^{-1}\right)$ under acidification conditions, and lowest $(622.9 \pm 133.7 \mu \mathrm{mol}$
$\mathrm{O}_{2} \mathrm{~g}^{-1} \mathrm{DW} \mathrm{h} \mathrm{h}^{-1}$ ) under warming conditions. There was a trend towards higher rates of photosynthesis in the elevated $\mathrm{CO}_{2}$ conditions (acidification and greenhouse; hereafter EC) $(\mathrm{F}=6.986, \mathrm{p}=0.030)$, while the elevated temperature condition (warming and greenhouse; hereafter ET) negatively impacted $\mathrm{GP}_{\text {max }}(\mathrm{F}=6.366, \mathrm{p}=0.036)$. Given that increased photosynthesis under EC was offset by reduced photosynthetic rates under ET, GP of $U$. pertusa grown under greenhouse conditions did not exhibit any differences in GP relative to present conditions. There were also no differences in photosynthetic efficiency $(\alpha)$ and minimum saturation irradiance $\left(E_{\mathrm{k}}\right)$ among the treatments. Dark respiration $\left(\mathrm{R}_{\mathrm{d}}\right)$ ranged between 68.6 and $252.7 \mu \mathrm{mol} \mathrm{O}_{2} \mathrm{~g}^{-1} \mathrm{DW} \mathrm{h} \mathrm{h}^{-1}$, with the highest $\mathrm{R}_{\mathrm{d}}$, observed under the present conditions nearly 2.5 -fold higher than under the warming conditions. Consequently, $R_{d}$ appeared to depend most upon temperature change, i.e., $\mathrm{R}_{\mathrm{d}}$ of ambient temperature had twice as high as ET ( $\mathrm{F}=$ $11.206, p=0.010$ ), while $R_{d}$ did not appear to be impacted by EC conditions ( $p>0.05$ ).

The maximum quantum yields of PSII $\left(F_{\mathrm{v}} / F_{\mathrm{m}}\right)$ ranged from 0.74 to 0.77 , but there were no significant difference among the treatments (Table 2). However, there was a trend in which $F_{\mathrm{v}} / F_{\mathrm{m}}$ was slightly decreased under ET conditions and increased under EC conditions, but again these patterns were no significant. Similarly, maximum electron transport rates $\left(r \mathrm{ETR}_{\mathrm{m}, \mathrm{RLC}}\right)$, electron transport efficiency $\left(\alpha_{\mathrm{RLC}}\right)$ and minimum saturation irradiance $\left(E_{\mathrm{k}, \mathrm{RLC}}\right)$, as determined from the RLC, were also not significantly different among the treatments.

Table 1. Photosynthetic parameters of Ulva pertusa obtained from the four temperature and $\mathrm{CO}_{2}$ conditions $(\mathrm{n}=3$, mean $\pm S D)$

\begin{tabular}{lcccr}
\hline & \multicolumn{1}{c}{ GP $_{\max }$} & $\boldsymbol{\alpha}$ & $\boldsymbol{E}_{\mathrm{k}}$ & $\mathbf{R}_{\mathbf{d}}$ \\
\hline Present & $783.7 \pm 232.4^{\mathrm{ab}}$ & $31.5 \pm 22.3$ & $40 \pm 37$ & $228.4 \pm 11.1^{\mathrm{a}}$ \\
Warming & $622.9 \pm 133.7^{\mathrm{a}}$ & $12.9 \pm 6.3$ & $53 \pm 17$ & $91.7 \pm 20.6^{\mathrm{b}}$ \\
Acidification & $1,046.9 \pm 66.5^{\mathrm{b}}$ & $34.4 \pm 25.2$ & $42 \pm 23$ & $202.4 \pm 62.8^{\mathrm{ab}}$ \\
Greenhouse & $793.5 \pm 67.1^{\mathrm{ab}}$ & $19.5 \pm 16.8$ & $62 \pm 38$ & $149.5 \pm 71.6^{\mathrm{ab}}$ \\
\hline
\end{tabular}

Different superscripted letters indicate significant differences based on Tukey's multiple comparison $(p<0.05)$.

$\mathrm{SD}$, standard deviation; $\mathrm{GP}_{\max }$ and $\mathrm{R}_{\mathrm{d}}$, maximum gross photosynthetic rate and dark respiration rate $\left(\mu \mathrm{mol} \mathrm{O}_{2} \mathrm{~g}^{-1} \mathrm{DW} \mathrm{h}^{-1}\right.$ ), a, photosynthetic efficiency $\left(\mu \mathrm{mol} \mathrm{O} \mathrm{g}^{-1} \mathrm{DW} \mathrm{h}^{-1}\left[\mu \mathrm{mol} \text { photons } \mathrm{m}^{-2} \mathrm{~s}^{-1}\right]^{-1}\right), E_{\mathrm{k}}$, saturation irradiance ( $\mu \mathrm{mol}$ photons $\left.\mathrm{m}^{-2} \mathrm{~s}^{-1}\right)$.

Table 2. Chlorophyll $a$ fluorescence parameters of Ulva pertusa obtained from the four temperature and $\mathrm{CO}_{2}$ conditions $(n=3$, mean \pm SD)

\begin{tabular}{lllll}
\hline & $\boldsymbol{F}_{\mathrm{v}} / \boldsymbol{F}_{\mathrm{m}}$ & $\boldsymbol{r E T R}_{\mathrm{m}, \mathrm{RLC}}$ & $\boldsymbol{\alpha}_{\mathrm{RLC}}$ & $\boldsymbol{E}_{\mathrm{K}, \mathrm{RLC}}$ \\
\hline Present & $0.765 \pm 0.021$ & $204 \pm 32$ & $0.939 \pm 0.013$ & $217 \pm 34$ \\
Warming & $0.741 \pm 0.040$ & $165 \pm 9$ & $0.837 \pm 0.114$ & $198 \pm 23$ \\
Acidification & $0.768 \pm 0.022$ & $166 \pm 20$ & $0.924 \pm 0.030$ & $180 \pm 27$ \\
Greenhouse & $0.769 \pm 0.019$ & $192 \pm 10$ & $0.943 \pm 0.011$ & $204 \pm 10$ \\
\hline
\end{tabular}

Different superscripted letters indicate significant differences based on Tukey's multiple comparison $(p<0.05)$.

$\mathrm{SD}$, standard deviation; $F_{\mathrm{v}} / F_{\mathrm{m}}$, maximum quantum yield; $r$ ETR $\mathrm{R}_{\mathrm{m}, \mathrm{RL}}$, maximum relative electron transport rate $\left(\mu \mathrm{mol} \mathrm{e}^{-1} \mathrm{~m}^{-2} \mathrm{~s}^{-1}\right) ; a_{\mathrm{RLC}}$, electron transport efficiency $\left(\mu \mathrm{mol} \mathrm{e} \mathrm{e}^{-1} \mathrm{~m}^{-1}\left[\mu \mathrm{mol} \text { photons } \mathrm{m}^{-2} \mathrm{~s}^{-1}\right]^{-1}\right) ; E_{\mathrm{k}, \text { RLC }}$, saturation light of the rapid light curves (RLC) ( $\mu$ mol photons $\mathrm{m}^{-2} \mathrm{~s}^{-1}$ ). 


\section{External CA activity}

Gross photosynthesis (GP) in $U$. pertusa measured in the absence of $\mathrm{AZ}$ ranged from 386.5 to $876.3 \mu \mathrm{mol} \mathrm{O}_{2}$ $\mathrm{g}^{-1} \mathrm{DW} \mathrm{h} \mathrm{h}^{-1}$ when held at $70 \mu \mathrm{mol}$ photons $\mathrm{m}^{-2} \mathrm{~s}^{-1}$ (Fig. 2). Indeed, GP was significantly inhibited (by 8-52\%) in the presence of $\mathrm{AZ}(\mathrm{t}=5.180, \mathrm{p}<0.001)$. While $U$. pertusa possesses eCA activity as one of CCMs, this activity did not differ among the treatments. However, there was significant reduction (by 50\%) in GP under the ambient $\mathrm{CO}_{2}$ conditions (present and warming) relative to $\mathrm{EC}$ conditions $(\mathrm{F}=9.825, \mathrm{p}=0.017)$. Further, there were no significant impacts to photosynthesis caused by adding AZ under the different temperatures ( $p>0.05$ ), and not there were impacts of the combined effects of $\mathrm{CO}_{2}$ and temperature on eCA activity compared to the present condition.

\section{$\mathrm{Chl} a$, tissue nutrient, and glucose contents}

The trend for Chl $a$ contents was similar to that for photosynthetic rate (Table 3). Specifically, there was no significant difference among the treatments, though a trend was observed in which, Chl $a$ content was higher under EC conditions than under ambient $\mathrm{CO}_{2}$ conditions, but these differences were reduced with increasing temperature. Together, this indicates that Chl $a$ contents in $U$. pertusa tissues were not different under greenhouse condition relative to present condition, suggesting that ET offsets the increased $\mathrm{Chl} a$ concentration that is induced by EC.

The carbon and nitrogen contents in $U$. pertusa tissues were lower under ET conditions than in any of the other treatments (Table 3). Tissue P, in contrast, was highest under EC conditions and lowest under present conditions. However, individually and in combination, EC or ET levels significantly impacted neither elemental tissue contents or their ratios.

Glucose content within $U$. pertusa tissues was dependent on temperature $(\mathrm{F}=66.589, \mathrm{p}<0.001)$ but not $\mathrm{CO}_{2}$ conditions. Specifically, glucose was significantly greater

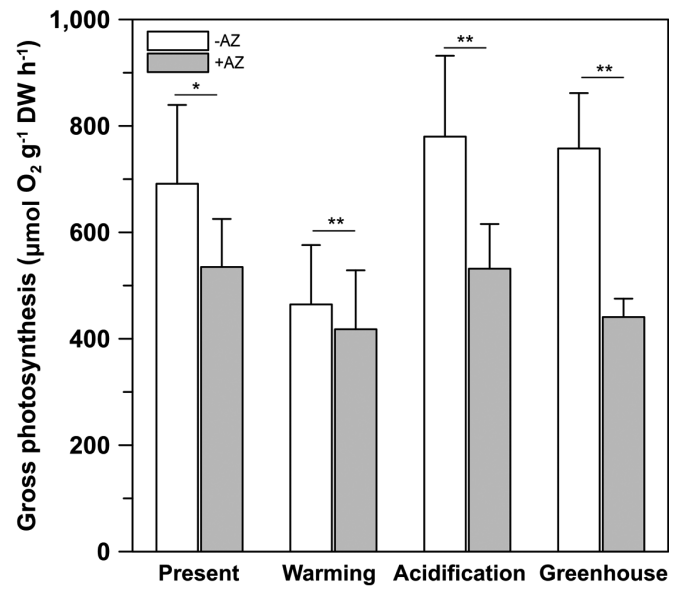

Fig. 2. Photosynthesis of Ulva pertusa under four $\mathrm{CO}_{2}$ and temperature conditions. Filled bars represent photosynthesis when acetazolamide (AZ) added. Data are presented as mean \pm standard deviation $\left(n=3,{ }^{*} p<0.05,{ }^{* *} p<0.01\right.$ for paired t-test between $-A Z$ and $+A Z$ and $p>0.05$ for photosynthesis between the four conditions).

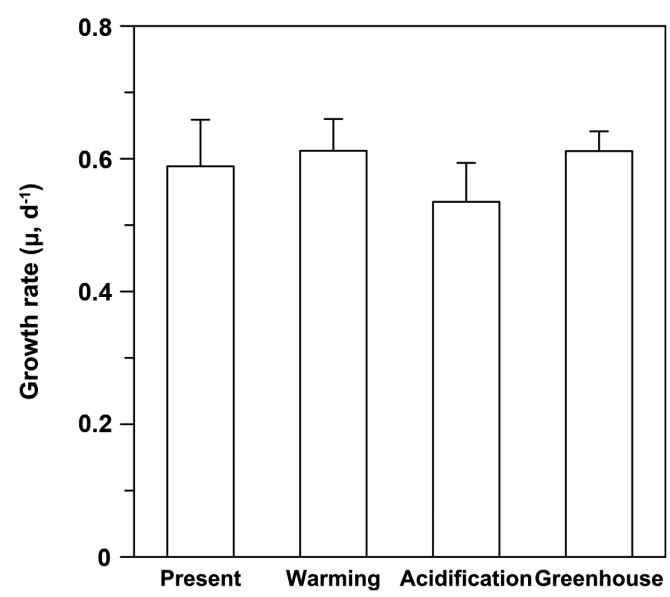

Fig. 3. Growth rate $(\mu)$ of Ulva pertusa under four $\mathrm{CO}_{2}$ and temperature conditions. Data are presented as mean \pm standard deviation ( $\mathrm{n}$ $=5, p>0.05$ ).

under EC conditions than present $\mathrm{CO}_{2}$ concentrations $(\mathrm{F}$ $=5.328, \mathrm{p}=0.05)$, while ET induced a significant decrease in the glucose content, by approximately $12 \%$ (Table 3 ).

Table 3. Chlorophyll a concentration ( $\mathrm{mg} \mathrm{Chl} \mathrm{a} \mathrm{g}^{-1} \mathrm{FW}$ ), tissue elemental contents (\%) and glucose content ( $\mathrm{mg} \mathrm{g}^{-1} \mathrm{DW}$ ) of Ulva pertusa obtained from the four temperature and $\mathrm{CO}_{2}$ conditions $(n=3-5$, mean \pm SD)

\begin{tabular}{lccccc}
\hline & Chl $\boldsymbol{a}$ & $\mathbf{C}$ & $\mathbf{N}$ & P & Reducing sugar \\
\hline Present & $1.698 \pm 0.309$ & $36.44 \pm 0.50$ & $4.57 \pm 0.15$ & $0.906 \pm 0.096$ & $125 \pm 3^{\mathrm{a}}$ \\
Warming & $1.575 \pm 0.291$ & $35.22 \pm 0.92$ & $4.52 \pm 0.02$ & $0.929 \pm 0.153$ & $109 \pm 2^{\mathrm{b}}$ \\
Acidification & $1.969 \pm 0.254$ & $36.33 \pm 0.49$ & $4.58 \pm 0.00$ & $1.071 \pm 0.079$ & $131 \pm 5^{\mathrm{a}}$ \\
Greenhouse & $1.773 \pm 0.357$ & $36.64 \pm 0.09$ & $4.64 \pm 0.09$ & $0.926 \pm 0.041$ & $113 \pm 4^{\mathrm{b}}$ \\
\hline
\end{tabular}

Different superscripted letters indicate significant differences based on Tukey's multiple comparison $(p<0.05)$.

SD, standard deviation. 


\section{Growth rate}

Growth rates $(\mu)$ ranged from 0.493 to 0.681 day $^{1}$, with the lowest $\mu$ occurring under EC conditions (Fig. 3). Although there were no significant differences among treatments, the $\mu$ trended higher under ET conditions, irrespective of $\mathrm{CO}_{2}$ levels $(\mathrm{F}=4.319, \mathrm{p}=0.054)$, and it appeared that EC did not impact the growth rates of $U$. pertusa $(\mathrm{p}>0.1)$. Lastly, the combined effect of $\mathrm{CO}_{2}$ and temperature did not elicit any difference on the growth rates.

\section{DISCUSSION}

It was shown previously that the growth rates of Ulva spp. were not significantly affected by enriched $\mathrm{CO}_{2}$ concentrations (Israel and Hophy 2002). The growth rate of $U$. pertusa in this study also did not differ between ambient and enhanced $\mathrm{CO}_{2}$ conditions, despite a slight upward trend in photosynthetic rates as $\mathrm{CO}_{2}$ levels rose (Figs 1 \& 3 ). The growth of $U$. pertusa appears to be largely decoupled from photosynthesis; for example, photosynthetic rates were low under ET conditions, whereas the species growth rates were slightly higher under ET conditions (Figs $2 \& 3$ ). This finding indicates that growth is regulated not only by photosynthesis but also by other mechanisms, including respiration rate and release of organic $\mathrm{C}$ compounds that restrict the contribution of $\mathrm{C}$ fixation to growth (Davison 1991). The $\mathrm{C}$ balance of photosynthesis and respiration controls plant growth (Cheng et al. 2000). The growth rates of $U$. linza, which with their massive green tide floating in the Yellow Sea in early summer, were close to zero at higher temperatures despite having high level of photosynthesis, most likely due to high respiration and extensive fragmentation offsetting increasing rates of photosynthesis (Kim et al. 2011, Kang et al. 2014, 2016). In our study, the rate of photosynthesis was not significantly different among the treatments, but respiration decreased as temperature increased, and trends in growth rates corresponded to photosynthesis / respiration ratios (GP / $R_{d}$ ratios) (data not shown). GP / $R_{d}$ ratios ranged from 2.5 to 4.9 in the four treatments, with these ratios being slightly higher under ET conditions, but not impacted by $\mathrm{CO}_{2}$ concentration. Such high GP / $\mathrm{R}_{\mathrm{d}}$ ratios suggest that photosynthates are used less for respiration and more for growth (Zou and Gao 2014). Indeed, Gordillo et al. (2001) showed a doubling in growth of $U$. rigida at high $\mathrm{CO}_{2}$ concentrations that were concurrent with a decline in organic carbon release when $\mathrm{N}$ was not limiting. Dissolved organic carbon (DOC) exudation, however, has been shown to increase in some eukaryotic phytoplankton under EC (Engel et al. 2005). Thus, it is possible that $U$. pertusa releases a large amount of DOC under EC, and this may affect its growth rate.

The highest growth rates of Ulva spp. have been observed at temperature between 10 and $20^{\circ} \mathrm{C}$ (Taylor et al. 2001), with various optimal temperatures for photosynthesis of $U$. pertusa reported for different locations: $15^{\circ} \mathrm{C}$ (Floreto et al. 1993), $20-25^{\circ} \mathrm{C}$ (Murase et al. 1993), and $20^{\circ} \mathrm{C}$ in Korean coastal waters (Kim et al. 2004). These differences are based on physiological variations among ecotypes adapted to particular geographic and seasonal conditions (Young et al. 1987, Schaum et al. 2013). In rocky shores of the south coast of Korea, for example, an intense bloom of $U$. pertusa often occurs during spring when seawater temperatures range between 12 and $18^{\circ} \mathrm{C}$ (Kim et al. 2004). Our experiment assumed $16^{\circ} \mathrm{C}$ to be the ambient temperature, with $19^{\circ} \mathrm{C}$ the elevated temperature condition, which correspond to the optimal temperature range for growth of Ulva species reported by Taylor et al. (2001). Further, our results show that while photosynthesis is negatively affected by high temperatures, growth is not. In general, high temperatures led to increased rates of respiration (Atkin and Tjoelker 2003), although we found that $R_{d}$ was higher under ambient temperature conditions. The low $\mathrm{R}_{\mathrm{d}}$ of $U$. pertusa under ET conditions reduces the loss of fixed $\mathrm{C}$ during dark periods, thereby increasing the fixed C used for growth (Davison et al. 1991), which may explain why there were no differences in growth rates among the four treatments.

Low eCA activity shows that organisms prefer $\mathrm{CO}_{2}$ or both $\mathrm{HCO}_{3}^{-}$and $\mathrm{CO}_{2}$ as primary photosynthetic substrates (Mercado et al. 1997). U. pertusa exhibited significant eCA activity, but this activity did not change under EC and / or ET conditions (Fig. 2). This suggests that photosynthesis may be saturated under current oceanic DIC conditions and the species prefers to use $\mathrm{CO}_{2}$. This result is consistent with previous observations of CA activity in Ulva species (Björk et al. 1993), although some researches have shown that AZ may significantly inhibit photosynthesis in U. linza (Israel and Hophy 2002).

In this study, increased $\mathrm{CO}_{2}$ concentrations and temperatures did not enhance photosynthesis, growth rates or biochemical composition, with the exception of glucose content (Table 3). However, photosynthetic pigment composition did change with $\mathrm{CO}_{2}$ concentration in previous studies. Specifically, $U$. rigida grown under different $\mathrm{CO}_{2}$ conditions exhibits decreased pigment contents at high $\mathrm{CO}_{2}$ (Gordillo et al. 2003), and the photosynthetic pigments of Gracilaria tenuistipitata likewise decreases 
when DIC is enriched $\left(5 \% \mathrm{CO}_{2}\right)$ (García-Sánchez et al. 1994). Further, Andria et al. (1999) showed similar results to those in our study in that DIC concentration did not impact the photosynthetic pigments of Gracilaria sp. In general, biochemical composition varies with nutrient conditions of the culture medium (Andria et al. 1999, Figueroa et al. 2009), and increasing $\mathrm{CO}_{2}$ concentrations enhance photosynthetic activity and increase nutrient uptake (Webber et al. 1994). Plants use tissue nutrients to supply the nutrient demand for photosynthesis, thereby nutrient limitation may occur under $\mathrm{CO}_{2}$ conditions. In this study, nutrients were replenished every 2 days, and as such nutrient limitation did not occur in any treatment, which may explain the absence of any significant differences in Chl $a$ concentrations and / or tissue element contents. Glucose content, which is related to rates of photosynthesis and respiration, was lower under high as opposed to ambient temperatures. Carbohydrates storage is related to photosynthetic supply or respiratory demand (Falkowski and Raven 2007); given that, photosynthesis trended lower under ET condition than under present or EC conditions, possibly explaining why glucose production was reduced in this study. Simultaneously, respiration was also reduced, and this might be related to the need to maintain carbon balance at lower glucose levels.

It is often argued that global climate change causes more frequent harmful algal blooms (Dale et al. 2006) but our results suggest that this may not be the case with $U$. pertusa. Increased temperatures above typical temperatures in the spring when the bloom naturally occurs do not appear to increase $U$. pertusa growth rates. We suggest that $U$. pertusa would not favor the rising temperatures associated with global climate change, and it is unlikely that the blooms would be shifted to winter because of light limitations on photosynthesis. Furthermore, higher $\mathrm{CO}_{2}$ levels did not significantly increase growth or photosynthesis. It could be that blooms of $U$. pertusa in Korean waters may not, in fact, change because of constraints by temperature. This does not preclude the possibility that other algal species with naturally occurring higher temperature requirements may be a source of blooms, especially since there is no prospect for regional declines in nutrient inputs and the resulting eutrophication of nearshore coastal environments. Increased temperature not only affects organisms directly but also influences the transport of nutrients from land-based sources to aquatic environments. Thus, future studies should combine climate change and other factors like light, nutrient loads, and salinity, given that many such factors will be altered by future $\mathrm{CO}_{2}$ concentrations and consequent temperature increases. For instance, photosynthetic responses related to temperature and $\mathrm{CO}_{2}$ depend on light availability (Kim et al. 2013), and net photosynthetic rate decreases with increasing temperatures at subsaturating light levels, whereas the light compensation point increases as temperature rise (Davison 1991).

In recent years, research has focused on the response of whole communities to increased $\mathrm{CO}_{2}$ and temperature. Rodolfo-Metalpa et al. (2011), for example, showed that the rising temperature could aggravate the benthic communities combined with ocean acidification in the Mediterranean Sea. In the case of the phytobenthos communities, the effects of rising $\mathrm{CO}_{2}$ levels singularly or combination with higher temperatures induced a variety of responses from individual or assemblages of macroalgal species, and high $\mathrm{CO}_{2}$ and high temperature were shown to reduce macroalgal assemblage biomass (Olabarria et al. 2013). There may also be a synergistic positive effect of high $\mathrm{CO}_{2}$ and high temperature on algal turfs, but changes in the algal turfs are also exacerbated kelp loss (Connell and Russell 2010). As mentioned above, the combined effects of $\mathrm{CO}_{2}$ and temperature vary and are complex at both the individual and community levels. Our research is relevant to understanding the changes in photosynthetic characteristics and growth responses of a coastal bloom-forming algal species with respect to future climate change as represented by ocean acidification and global warming.

\section{ACKNOWLEDGEMENTS}

We would like to thank Dr. J. -H. Kim for technical support and comments on the manuscript. This research was supported by the program on "Management of marine organisms causing ecological disturbance and harmful effects," which was funded by KIMST/MOF.

\section{REFERENCES}

Andria, J. R., Vergara, J. J. \& Perez-Llorens, J. 1999. Biochemical responses and photosynthetic performance of Gracilaria sp. (Rhodophyta) from Cádiz, Spain, cultured under different inorganic carbon and nitrogen levels. Eur. J. Phycol. 34:497-504.

Atkin, O. K., Edwards, E. J. \& Loveys, B. R. 2000. Response of root respiration to changes in temperature and its relevance to global warming. New Phytol. 147:141-154. 
Atkin, O. K. \& Tjoelker, M. G. 2003. Thermal acclimation and the dynamic response of plant respiration to temperature. Trends Plant Sci. 8:343-351.

Björk, M., Haglund, K., Ramazanov, Z. \& Pedersén, M. 1993. Inducible mechanisms for $\mathrm{HCO}_{3}{ }^{-}$utilization and repression of photorespiration in protoplasts and thalli of three species of Ulva (Chlorophyta). J. Phycol. 29:166-173.

Brading, P., Warner, M. E., Davey, P., Smith, D. J., Achterberg, E. P. \& Suggett, D. J. 2011. Differential effects of ocean acidification on growth and photosynthesis among phylotypes of Symbiodinium (Dinophyceae). Limnol. Oceanogr. 56:927-938.

Cheng, W., Sims, D. A., Luo, Y., Coleman, J. S. \& Johnson, D. W. 2000. Photosynthesis, respiration and net primary production of sunflower stands in ambient and elevated atmospheric $\mathrm{CO}_{2}$ concentrations: an invariant NPP:GPP ratio. Glob. Chang. Biol. 6:931-941.

Choi, T. S. 2003. Ecophysiological characteristics of green macroalga Ulva pertusa L. from eelgrass habitats. Ph.D. dissertation, Chonnam National University, Gwangju, Korea, pp. 89-118.

Connell, S. D. \& Russell, B. D. 2010. The direct effects of increasing $\mathrm{CO}_{2}$ and temperature on non-calcifying organisms: increasing the potential for phase shifts in kelp forests. Proc. R. Soc. B 277:1409-1415.

Dale, B., Edwards, M. \& Reid, P. C. 2006. Climate change and harmful algal blooms. In Granéli, E. \& Turner, J. T. (Eds.) Ecology of Harmful Algae. Springer, Berlin, pp. 367-378.

Davison, I. R. 1991. Environmental effects on algal photosynthesis: temperature. J. Phycol. 27:2-8.

Davison, I. R., Greene, R. M. \& Podolak, E. J. 1991. Temperature acclimation of respiration and photosynthesis in the brown alga Laminaria saccharina. Mar. Biol. 110:449-454.

de Casabianca, M. -L., Barthelemy, N., Serrano, O. \& Sfriso, A. 2002. Growth rate of Ulva rigida in different Mediterranean eutrophicated sites. Bioresour. Technol. 82:27-31.

Doney, S. C., Fabry, V. J., Feely, R. A. \& Kleypas, J. A. 2009. Ocean acidification: the other $\mathrm{CO}_{2}$ problem. Annu. Rev. Mar. Sci. 1:169-192.

Engel, A., Zondervan, I., Aerts, K., Beaufort, L., Benthien, A., Chou, L., Delille, B., Gattuso, J. -P., Harlay, J., Heemann, C., Hoffmann, L., Jacquet, S., Nejstgaard, J., Pizay, M. -D., Rochelle-Newall, E., Schneider, U., Terbrueggen, A. \& Riebesell, U. 2005. Testing the direct effect of $\mathrm{CO}_{2}$ concentration on a bloom of the coccolithophorid Emiliania huxleyi in mesocosm experiments. Limnol. Oceanogr. 50:493-507.

Falkowski, P. G. \& Raven, J. A. 2007. Aquatic photosynthesis. 2nd ed. Princeton University Press, Princeton, NJ, pp.
306-310.

Figueroa, F. L., Israel, A., Neori, A., Martínez, B., Malta, E. -J., Ang, P. Jr., Inken, S., Marquardt, R. \& Korbee, N. 2009. Effects of nutrient supply on photosynthesis and pigmentation in Ulva lactuca (Chorophyta): responses to shortterm stress. Aquat. Biol. 7:173-183.

Floreto, E. A. T., Hirata, H., Ando, S. \& Yamasaki, S. 1993. Effects of temperature, light intensity, salinity and source of nitrogen on the growth, total lipid and fatty acid composition of Ulva pertusa Kjellman (Chlorophyta). Bot. Mar. 36:149-158.

Fu, F. -X., Warner, M. E., Zhan, Y., Feng, Y. \& Hutchins, D. A. 2007. Effects of increased temperature and $\mathrm{CO}_{2}$ on photosynthesis, growth, and elemental ratios in marine Synechococcus and Prochlorococcus (cyanobacteria). J. Phycol. 43:485-496.

Gao, K., Helbling, E. W., Häder, D. -P. \& Hutchins, D. A. 2012. Responses of marine primary producers to interactions between ocean acidification, solar radiation, and warming. Mar. Ecol. Prog. Ser. 470:167-189.

García-Sánchez, M. J., Fernández, J. A. \& Niell, X. 1994. Effect of inorganic carbon supply on the photosynthetic physiology of Gracilaria tenuistipitata. Planta 194:55-61.

Gessner, F. 1970. Temperature: plants. In Kinne, O. (Ed.) Marine Ecology: A Comprehensive, Integrated Treatise on Life in Oceans and Coastal Waters. Vol. 1. Environmental Factors. Wiley Interscience, New York, pp. 363-406.

Giannotti, A. L. \& McGlathery, K. J. 2001. Consumption of Ulva lactuca (Chlorophyta) by the omnivorous mud snail Ilyanassa obsoleta (Say). J. Phycol. 37:209-215.

Gordillo, F. J. L., Figueroa, F. L. \& Niell, F. X. 2003. Photon- and carbon-use efficiency in Ulva rigida at different $\mathrm{CO}_{2}$ and N levels. Planta 218:315-322.

Gordillo, F. J. L., Niell, F. X. \& Figueroa, F. L. 2001. Non-photosynthetic enhancement of growth by high $\mathrm{CO}_{2}$ level in the nitrophilic seaweed Ulva rigida C. Agardh (Chlorophyta). Planta 213:64-70.

Hansen, J., Nazarenko, L., Ruedy, R., Sato, M., Willis, J., Del Genio, A., Koch, D., Lacis, A., Lo, K., Menon, S., Novakov, T., Perlwitz, J., Russell, G., Schmidt, G. A. \& Tausnev, N. 2005. Earth's energy imbalance: confirmation and implications. Science 308:1431-1435.

Innes, D. J. 1988. Genetic differentiation in the intertidal zone in populations of the alga Enteromorpha linza (Ulvales: Chlorophyta). Mar. Biol. 97:9-16.

Inskeep, W. P. \& Bloom, P. R. 1985. Extinction coefficients of chlorophyll $a$ and $b$ in $N, N$-dimethylformamide and 80\% acetone. Plant Physiol. 77:483-485.

IPCC 2007. Summary for policymakers. In Solomon, S., Qin, D., Manning, M., Chen, Z., Marquis, M., Averyt, K. B., 
Tignor, M. \& Miller, H. L. (Eds.) Climate Change 2007: The Physical Science Basis. Contribution of Working Group I to the Fourth Assessment Report of the Intergovernmental Panel on Climate Change. Cambridge University Press, Cambridge, pp. 1-18.

Israel, A. \& Hophy, M. 2002. Growth, photosynthetic properties and Rubisco activities and amounts of marine macroalgae grown under current and elevated seawater $\mathrm{CO}_{2}$ concentrations. Glob. Chang. Biol. 8:831-840.

Johnston, A. M., Maberly, S. C. \& Raven, J. A. 1992. The acquisition of inorganic carbon for four red macroalgae. Oecologia 92:317-326.

Kang, E. J., Kim, J. -H., Kim, K., Choi, H. -G. \& Kim, K. Y. 2014. Re-evaluation of green tide-forming species in the Yellow Sea. Algae 29:267-277.

Kang, E. J., Kim, J. -H., Kim, K. \& Kim, K. Y. 2016. Adaptations of a green tide forming Ulva linza (Ulvophyceae, Chlorophyta) to selected salinity and nutrients conditions mimicking representative environments in the Yellow Sea. Phycologia 55:210-218.

Kim, J. -H., Kang, E. J., Park, M. G., Lee, B. -G. \& Kim, K. Y. 2011. Effects of temperature and irradiance on photosynthesis and growth of a green-tide-forming species (Ulva linza) in the Yellow Sea. J. Appl. Phycol. 23:421-432.

Kim, J. -H., Kim, K. Y., Kang, E. J., Lee, K., Kim, J. -M., Park, K. -T., Shin, K., Hyun, B. \& Jeong, H. J. 2013. Enhancement of photosynthetic carbon assimilation efficiency by phytoplankton in the future coastal ocean. Biogeosciences 10:7525-7535.

Kim, J. -M., Shin, K., Lee, K. \& Park, B. -K. 2008. In situ ecosystem-based carbon dioxide perturbation experiments: design and performance evaluation of a mesocosm facility. Limnol. Oceanogr. Methods 6:208-217.

Kim, K. Y., Choi, T. S., Kim, J. H., Han, T., Shin, H. W. \& Garbary, D. J. 2004. Physiological ecology and seasonality of Ulva pertusa on a temperate rocky shore. Phycologia 43:483-492.

Kim, K. Y. \& Lee, I. K. 1996. The germling growth of Enteromorpha intestinalis (Chlorophyta) in laboratory culture under different combinations of irradiance and salinity and temperature and salinity. Phycologia 35:327-331.

Koch, M., Bowes, G., Ross, C. \& Zhang, X. -H. 2013. Climate change and ocean acidification effects on seagrasses and marine macroalgae. Global Chang. Biol. 19:103-132.

Kübler, J. E. \& Davison, I. R. 1995. Thermal acclimation of light-use characteristics of Chondrus crispus (Rhodophyta). Eur. J. Phycol. 30:189-195.

Lewis, E. \& Wallace, D. W. R. 1998. CO2SYS-Program developed for the $\mathrm{CO}_{2}$ system calculations. Report ORNL/CDI$A C$-105. Carbon Dioxide Information Analysis Center,
Oak Ridge, TN, 21 pp.

Lüning, K. 1990. Seaweeds: their environment, biogeography and ecophysiology. Wiley, New York, $544 \mathrm{pp}$.

Menzel, D. W. \& Corwin, N. 1965. The measurement of total phosphorus in seawater based on the liberation of organically bound fractions by persulfate oxidation. Limnol. Oceanogr. 10:280-282.

Mercado, J. M., Figueroa, F. L., Niell, F. X. \& Axelsson, L. 1997. A new method for estimating external carbonic anhydrase activity in macroalgae. J. Phycol. 33:999-1006.

Murase, N., Maegawa, M., Matsui, T., Ohgai, M., Katayama, N., Saitoh, M. \& Yokohama, Y. 1993. Growth and photosynthesis termperature characteristics of the sterile Ulva pertusa. Nippon Suisan Gakkaish 60:625-630.

Olabarria, C., Arenas, F., Viejo, R. M., Gestoso, I., Vaz-Pinto, F., Incera, M., Rubal, M., Cacabelos, E., Veiga, P. \& Sobrino, C. 2013. Response of macroalgal assemblages from rockpools to climate change: effects of persistent increase in temperature and $\mathrm{CO}_{2}$. Oikos 122:1065-1079.

Platt, T., Gallegos, C. L. \& Harrison, W. G. 1980. Photoinhibition of photosynthesis in natural assemblage of marine phytoplankton. J. Mar. Res. 38:687-701.

Ralph, P. J. \& Gademann, R. 2005. Rapid light curves: a powerful tool to assess photosynthetic activity. Aquat. Bot. 82:222-237.

Raven, J. A. 1997. Inorganic carbon acquisition by marine autotrophs. Adv. Bot. Res. 27:85-209.

Rodolfo-Metalpa, R., Houlbrèque, F., Tambutté, É., Boisson, F., Baggini, C., Patti, F. P., Jeffree, R., Fine, M., Foggo, A., Gattuso, J. -P. \& Hall-Spencer, J. M. 2011. Coral and mollusk resistance to ocean acidification adversely affected by warming. Nat. Clim. Chang. 1:308-312.

Schaum, E., Rost, B., Millar, A. J. \& Collins, S. 2013. Variation in plastic responses of a globally distributed picoplankton species to ocean acidification. Nat. Clim. Chang. 3:298-302.

Taylor, R., Fletcher, R. L. \& Raven, J. A. 2001. Preliminary studies on the growth of selected 'green-tide' algae in laboratory culture: effects of irradiance, temperature, salinity and nutrients on growth rate. Bot. Mar. 44:327-336.

Valiela, I., McClelland, J., Hauxwell, J., Behr, P. J., Hersh, D. \& Foreman, K. 1997. Macroalgal blooms in shallow estuaries: controls and ecophysiological and ecosystem consequences. Limnol. Oceanogr. 42:1105-1118.

Vona, V., Rigano, V. D. M., Lobosco, O., Carfagna, S., Esposito, S. \& Rigano, C. 2004. Temperature responses of growth, photosynthesis, respiration and $\mathrm{NADH}$ : nitrate reductase in cryophilic and mesophilic algae. New Phytol. 163:325-331.

Webber, A. N., Nie, G. -Y. \& Long, S. P. 1994. Acclimation of 
photosynthetic proteins to rising atmospheric $\mathrm{CO}_{2}$. Photosynth. Res. 39:413-425.

Wood, T. M. \& Bhat, K. M. 1988. Methods for measuring cellulase activities. Methods Enzymol. 160:87-112.

$\mathrm{Xu}$, J. \& Gao, K. 2012. Future $\mathrm{CO}_{2}$-induced ocean acidification mediates the physiological performance of a green tide alga. Plant Physiol. 160:1762-1769.

Young, A. J., Collins, J. C. \& Russell, G. 1987. Ecotypic variation in the osmotic responses of Enteromorpha intestinalis (L.) Link. J. Exp. Bot. 38:1309-1324.

Zimmerman, R. C., Kohr, D. G., Steller, D. L. \& Alberte, R. S. 1997. Impacts of $\mathrm{CO}_{2}$ enrichment on productivity and light requirements of eelgrass. Plant Physiol. 115:599607.
Zou, D. \& Gao, K. 2013. Thermal acclimation of respiration and photosynthesis in the marine macroalga Gracilaria lemaneiformis (Gracilariales, Rhodophyta). J. Phycol. 49:61-68.

Zou, D. \& Gao, K. 2014. The photosynthetic and respiratory responses to temperature and nitrogen supply in the marine green macroalga Ulva conglobata (Chlorophyta). Phycologia 53:86-94.

Zou, D., Gao, K. \& Luo, H. 2011. Short- and long-term effects of elevated $\mathrm{CO}_{2}$ on photosynthesis and respiration in the marine macroalga Hizikia fusiformis (Sargassaceae, Phaeophyta) grown at low and high N supplies. J. Phycol. 47:87-97. 